\title{
The levels of readiness of science teacher candidates regarding the strengths of binary, organic and oxy acids, and their gains over the course of their educational periods
}

\author{
Dilek Çelikler \\ Primary Education Department, Ondokuz Mayıs University, Samsun, Turkey \\ Email address: \\ dilekc@omu.edu.tr, dilekcelikler@hotmail.com
}

\section{To cite this article:}

Dilek Çelikler. The Levels of Readiness of Science Teacher Candidates Regarding the Strengths of Binary, Organic and Oxy Acids, and their Gains over the Course of their Educational Periods. Education Journal. Vol. 3, No. 1, 2014, pp. 7-14.

doi: 10.11648/j.edu.20140301.12

\begin{abstract}
This study was performed with 49 science teacher candidates in order to determine their levels of readiness regarding the strength of binary, organic and oxy acids, and to assess how much progress they have made as a result of their four-year education.In this study, 9 open-ended questions were initially addressed to the teacher candidates at the beginning of the $1^{\text {st }}$ semester to determine their levels of readiness. These questions were later asked once again to the same teacher candidates at the end of the $8^{\text {th }}$ semester to assess their level of knowledge following their four-year education. The teacher candidates were requested to answer the questions with drawings as well as in writing. When analyzing the questions, the level of knowledge of the teacher candidates were grouped according to their drawings and written answers, based on the levels used by Bartoszeck, Machado and Amann-Gainotti (2008) and Uzunkavak (2009a, 2009b). According to the study's results, it was determined that the teacher candidates' levels of readiness were low, and that although their level of performance increased at end of their four-year education, their knowledge on the matter was still insufficient.
\end{abstract}

Keywords: Science Teacher Candidates, Binary Acid, Organic Acid, Oxyacid, Readiness, Drawing

\section{Introduction}

Readiness is an extremely important aspect of education and learning, and constitutes an important input in teaching and learning systems (Bloom, 1995). Readiness is the preparedness of the nervous system for learning activities (Binbaşığlu, 1995), the acquisition of the necessary prerequisite behaviors for performing certain learning activities (Ülgen, 1997; Y1lmaz and Sünbül, 2003), the individual'sability to perform a certain developmental assignment through maturation and learning (Başaran, 1998), the cognitive, affective, social and psychomotor preparedness for carrying out any activity, and a measure the level of preparedness of the individual for such activities. Readiness represents the individual's beginning level for a given subject, and encompasses the individual's preliminary knowledge and attitude on the subject (Yenilmez and Kakmac1, 2008). Preliminary knowledge may have an obstructive and slowing, or a supportive and accelerating effect fornew information to be learned (Ersanlı and Uzman, 2007).

When assessing the levels of readiness, students of different levels of readiness may be encountered. For this reason, it necessary for educational activities to be organized effectively. For students with low levels of readiness, simple activities that will complement their lack of knowledge, consisting of few concrete steps and similar to their previous experiences should be organized. For students with high levels of readiness, on the other hand, activities in which they were previously successful could be skipped, and more complex, abstract and multifaceted activities could be organized (Yenilmez and Kakmac1, 2008).

Determining the students' levels of readiness is of considerable importance for ensuring the efficiency of the education process.For this reason, by determining the levels 
of readiness, the aim is to identify beforehand what the students know prior to beginning a certain subject, to determine the standards they have on an individual basis, and to ascertain whether the information needs to be taught again or whether progress has been made (Yüksel, Marangoz and Canaran, 2004). Drawings can be used effectively for the purposes of measuring and assessing the students' levels of readiness and knowledge.

The use of drawings is an effective approach, since it takes less time than methods that determine thought processes with writing and behavior-based scales, and can present a variety of information at the same time.The knowledge and misconceptions of students can be determined with the aid of drawings (White and Gunstone, 1992). Drawings allow students to express their knowledge and beliefs without being constrained by words (Ayas, 2006).

Acid are one of the subjects of basic chemistry.Theyhave a wide array of uses.In addition to acting as catalysts in many chemical reactions, they also play an important role in the reactions within the human body. For example, as a stomach acid, $\mathrm{HCl}$ plays an important role in the digestion of food. In addition, acids have a wide range of uses in cleaning products and various industries, and are integral in the structure of certain foods. Due to importance of acids in daily life, being able to provide meaningful and lasting learning on acids during science education is also important. To this end, this study was performed in order to determine the levels of readiness of science teacher candidates regarding the strength of binary, organic and oxy acids, and the progress they achieved as a result of their four-year education.

\section{Methods}

\subsection{Participants}

This study was conducted with 49 teacher candidates receiving their education in the Department of Science Education of a public university in the Black Sea region of Turkey.

\subsection{Data Collection Tool}

In this study, data were collected by using 9 open-ended questions on the strength of binary, organic and oxy acids.The questions were first asked during the General Chemistry course at the beginning of the $1^{\text {st }}$ Semester to assess the levels of readiness of the teacher candidates. The questions were then asked once again at the end of the $8^{\text {th }}$ semester to determine, for the same students, the effect of the levels of readiness on the levels of knowledge at the end of the four-year education period. The teacher candidates were asked to answer the questions with drawings as well as in writing.In addition, the names of the teacher candidates were kept confidential and encoded with letters. Examples of the answers provided by the teacher candidates are included in this manuscript.

\subsection{Data Analysis}

When analyzing the questions, the level of knowledge of the teacher candidates were grouped according to the drawings and writings they provided for the questions, based on the levels previously used by Bartoszeck, Machado and Amann-Gainotti (2008) and Uzunkavak (2009a, 2009b).

The level groups that were defined in order to assess the science teacher candidates' knowledge based on their drawings are provided in Table 1.

Table 1. Level groups defined in order to assess the level of knowledge with drawings

\section{Levels Description}

Level 1 No knowledge / drawing provided

Level 2 Erroneous knowledge / drawing

Level 3 Partially correct knowledge / drawing

Level 4 Incomplete knowledge / drawing

Level 5 Entirely correct and complete knowledge / drawing

\section{Results}

The percentage distributionof the answersgiven by the science teacher candidates to the question "Explain the concept of acid" in the $1^{\text {st }}$ and $8^{\text {th }}$ semesters are provided with respect to the level groups in Graph 1. Examples of the answers provided by the science teachers in both semesters are shown in Figure 1 and Figure 2.

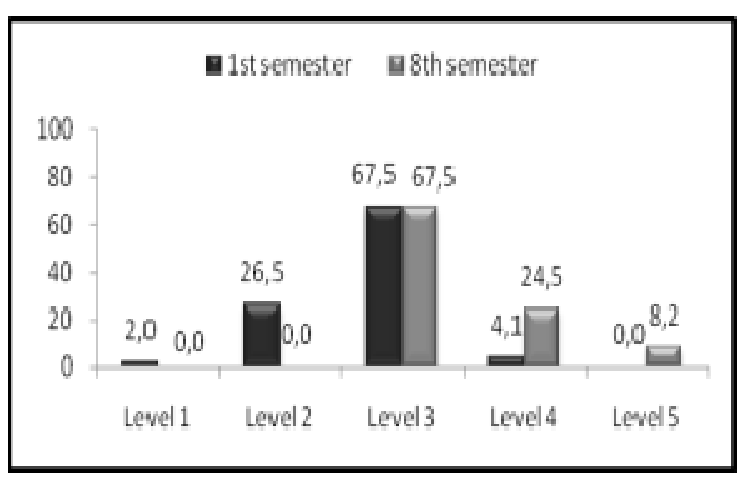

Graph 1. The percentage distribution of the answers to question 1

It was noted that $67.5 \%$ of the teacher candidates provided partially correct explanations (level 3) for the concept of acid inthe $1^{\text {st }}$ semester, while none of the teacher candidates provided an entirely correct explanation (level $5)$. In the $8^{\text {th }}$ semester, on the other hand, it was determined that $67.5 \%$ of the teacher candidates provided partially correct explanations (level 3) to the same question, while $8.2 \%$ of the teacher candidates provided entirely correct explanations.

Substances that provide $H^{+}$to their environment are acids. Their $\mathrm{pH}$ value is less than 7.

Figure 1. Science teacher candidate $A^{\prime}$ s answer to question 1 in the $1^{\text {st }}$ semester 
When Figure 1 is evaluated, it can be seen that the science teacher candidate A defined acids as substances that provide $\mathrm{H}^{+}$ions to their environment. The fact that this teacher candidate explained only a single aspect of this concept demonstrated partially correct knowledgeon the concept of acids.

- According to the Lowry Bronsted and acid-base theory...

- According to Arrhenius, molecules with $\mathrm{H}^{+}$ions are acids. However, he was not able to explain $\mathrm{NH}_{3}$.

- According to Arrhenius, molecules with $\mathrm{OH}$ are bases.

- According to Lowry Bronsted, substances that give protons to their environment are acids, while substances that take protons from their environment are bases.

- Also, as the reaction of salts such as $\mathrm{OCl}^{-}$with $\mathrm{H}_{2} \mathrm{O}$ leads to the formation of $\mathrm{OH}$ ions, such substances are bases.

Figure 2. Science teacher candidate A's answer to question 1 in the $8^{\text {th }}$ semester

As it can be seen in Figure 2, the same teacher candidate correctly explained the concept of acid in the $8^{\text {th }}$ semester according to both Arrhenius' and Lowry-Bronsted's theories. It was hence determined that the teacher candidate had an entirely correct and complete knowledge of the subject.

The percentage distribution of the answers given by the science teacher candidates to the question "what does the strength of an acid depend on?" in the $1^{\text {st }}$ and $8^{\text {th }}$ semesters are provided with respect to the level groups in Graph 2. The answers provided by the science teacher candidate $\mathrm{B}$ in both semesters are shown in Figure 3 and Figure 4.

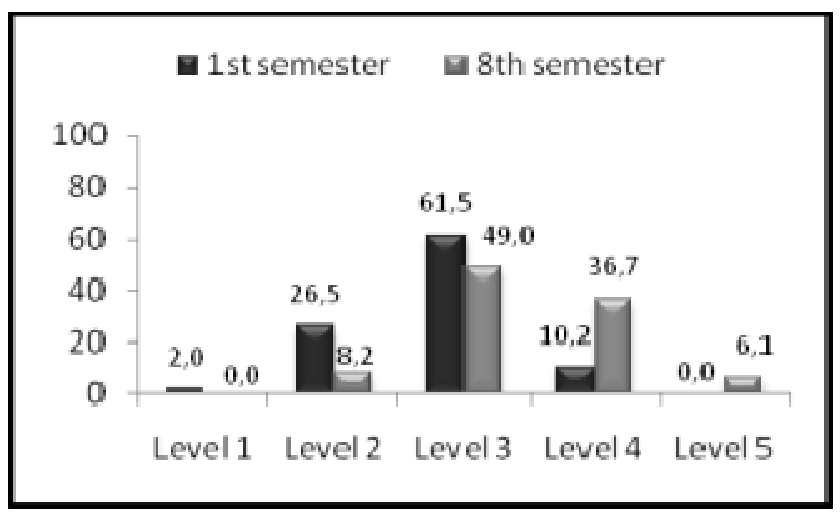

Graph 2. The percentage distribution of the answers to question 2

In the $1^{\text {st }}$ semester, $26.5 \%$ of the teacher candidates provided incorrect explanations (level 2) regarding the factors that determine the strength of acids, while $61.5 \%$ provided partially correct explanations (level 3).However, none of the teacher candidates were able to provide correct explanations for thisquestion. In the $8^{\text {th }}$ semester, on the other hand, $49.0 \%$ of the teacher candidates provided partially correct explanations (level 3), while 36.7\% provided correct but incomplete explanations (level 4).It was also observed that $6.1 \%$ of the teacher candidates provided entirely correct explanations to the question.

The acid that undergoes more ionization in water is a strong acid, while the acid that undergoes less ionization is a weak acid. This is what we have to look for.

Figure 3. Science teacher candidate B's answer to question 2 in the $1^{\text {st }}$ semester

When Figure 3 is evaluated, it can be seen that the science teacher candidate $\mathrm{B}$ described the acid that undergoes more ionization in water as the stronger acid, while describing the acid that undergoes less ionization as the weaker acid. The fact that the teacher candidate described the strength of acids by only taking ionization into account demonstrated apartially correct knowledge on the subject.

To be able to determine whether an acid is weak or strong, we can determine its:

- Electronegativity

- Acid constant

- Bond structure

Acid strength can be determined according to these.

Figure 4. Science teacher candidate B's answer to question 2 in the $8^{\text {th }}$ semester

As it can be seen in Figure 4, the same teacher candidate explained in the $8^{\text {th }}$ semester that it is necessary to look at the electronegativity, acid constant and bond structure when determining the strength of acids. This demonstrates that the teacher candidate had correct but incomplete knowledge on the subject.

The percentage distribution of the answers given by the science teacher candidates to the question "list the strength of the binary acids $\mathrm{HI}, \mathrm{HBr}, \mathrm{HF}, \mathrm{HCl}$, and provide your reasons for this ranking" in the $1^{\text {st }}$ and $8^{\text {th }}$ semesters are provided with respect to the level groups in Graph 3. The answers provided by the science teacher candidate $\mathrm{C}$ in both semesters are shown in Figure 5 and Figure 6.

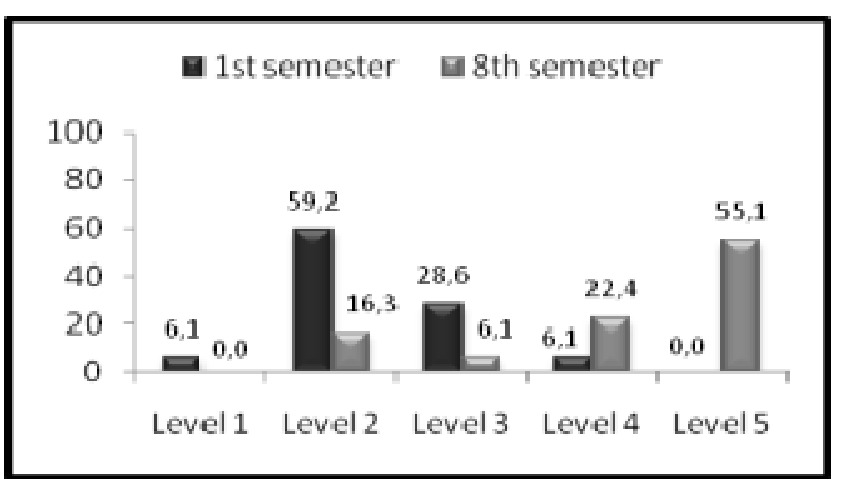

Graph 3. The percentage distribution of the answers to question 3 
In the $1^{\text {st }}$ semester, it was observed that $59.2 \%$ of the teacher candidates listed the strength of the $\mathrm{HI}, \mathrm{HBr}, \mathrm{HF}$, $\mathrm{HCl}$ binary acids incorrectly (level 2 ), while only $28.6 \%$ provided a partially correct rankingfor the acids (level 3 ). None of the teacher candidates were able to provide an entirely correct ranking for the acid strengths. However, it was observed that there were still teacher candidates (22.4\%) with correct but incomplete knowledge (level 4).

We can list the acids as $\mathrm{HF}<\mathrm{HCl}<\mathrm{HBr}^{-}<\mathrm{HI}$ according
to their strengths.
Here, reactivity can lead to increase in the tendency to
acquire electrons.

Figure 5. Science teacher candidate $C^{\prime}$ s answer to question 3 in the $1^{\text {st }}$ semester

When Figure 5 is evaluated, it can be seen that the science teacher candidate $\mathrm{C}$ listed the acid strengths correctly, but that the explanation provided by this teacher candidate for this rankingwasincorrect.Based this explanation, it can be seen that the teacher candidate had incorrect knowledge of the subject.

$\mathrm{HF}, \mathrm{HI}, \mathrm{HBr}, \mathrm{HCl} \ldots \mathrm{Here}$, as a general rule, electronegativity decreases when we go down a period. The acidity increases as a result.

Thus, $\mathrm{HI}>\mathrm{HBr}>\mathrm{HCl}>\mathrm{HF}$,"

Figure 6. Science teacher candidate $C^{\prime}$ s answer to question 3 in the $8^{\text {th }}$ semester

As it can be seen in Figure 6, the science teacher candidate C's explanation in the $8^{\text {th }}$ semester that electronegativity decreases when moving down the periodic table, and that this consequently increases the acidity, demonstratedan incomplete knowledge of the subject.This is because the teacher candidate attempted to provide an explanation without mentioning bond lengths and bond dissociation energies.

The percentage distribution of the answersgiven by the science teacher candidates to the question "Explain which of the compounds $\mathrm{CH}_{4}, \mathrm{NH}_{3}, \mathrm{H}_{2} \mathrm{O}, \mathrm{HF}$ are acids by providing your reasons" in the $1^{\text {st }}$ and $8^{\text {th }}$ semester are provided with respect to the level groups in Graph 4. Examples of the answers provided by the science teacher candidate D in both semesters are shown in Figure 7 and Figure 8 .

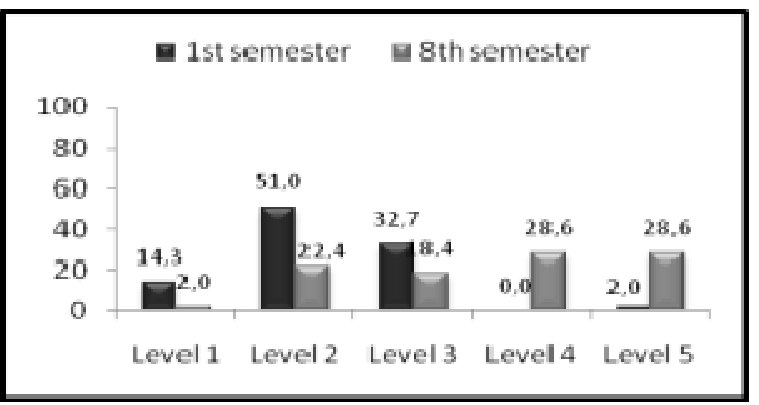

Graph 4. The percentage distributions of the answers to question 4
In the first semester, it was noted that $51.0 \%$ of the teacher candidates provided incorrect answers (level 2) regarding which of the $\mathrm{CH}_{4}, \mathrm{NH}_{3}, \mathrm{H}_{2} \mathrm{O}$ and $\mathrm{HF}$ compounds should be characterized as acids, while $14.3 \%$ had no knowledge on the subject. In the $8^{\text {th }}$ semester, it was observed that $28.6 \%$ of the teacher candidates had correct but incomplete (level 4), or entirely correct (level 5) knowledge on this subject.

\begin{tabular}{|c|}
\hline $\begin{array}{l}\mathrm{CH}_{4}+\mathrm{H}_{2} \mathrm{O} \leftrightarrow \mathrm{CH}_{3}^{+}+\mathrm{OH} \\
\text { Base }\end{array}$ \\
\hline $\mathrm{NH}_{3}+\mathrm{H}_{2} \mathrm{O} \leftrightarrow \mathrm{NH}_{4}^{+}+\mathrm{OH}$ \\
\hline Base \\
\hline $\mathrm{H}_{2} \mathrm{O} \leftrightarrow \mathrm{H}^{+}+\mathrm{OH}^{-}$(Neutral) \\
\hline $\begin{array}{l}H F+H 2 O \leftrightarrow H^{+}+F \\
\text { Base } \quad \text { Acid }\end{array}$ \\
\hline
\end{tabular}

Figure 7. Science teacher candidate D's answer to question 4 in the $1^{\text {st }}$ semester

When Figure 7 is evaluated, it can be seen that science teacher candidate $\mathrm{C}$ attempted to provide explanation by writing down the reaction for each one of these substances with water; however, the written reactions are incorrect, and the provided explanation is hence incomplete. For instance, the compound HF was erroneously written as a base.

$\mathrm{CH}_{4}, \mathrm{H}_{2} \mathrm{O}, \mathrm{HF}, \mathrm{NH}_{3}$

HF: Due to the F element, there is hydrogen bond here. The presence of the hydrogen bond increases acidity. Consequently, Hydrogen Fluoride demonstrates strong acidity.

$\underline{\mathrm{H}_{2}} \mathrm{O}$ : Consists of $2 \mathrm{~mol}$ hydrogen and $1 \mathrm{~mol}$ oxygen. Water is a polar compound. Water has low acidity.

$\underline{\mathrm{CH}}_{4}:$ Methane is an organic compound. It is neither acidic nor basic.

$\mathrm{NH}_{3}:$ Bonds are nonpolar. Ammonia is not acidic. Ammonia is a weak base.

Figure 8. Science teacher candidate D's answer to question 1 in the $8^{\text {th }}$ semester

As it can be seen in Figure 8, the science teacher candidate $\mathrm{D}$ does not mention bond polarity and the differences in electronegativity when describing compound $\mathrm{HF}$ as an acid in the $8^{\text {th }}$ semester. Moreover, the teacher candidate described HF as a strong acid, while it is actually a moderately strong acid.

The percentage distributionofthe answers given by the science teachers candidates to the question "Explain which one of the acids $\mathrm{HOCl} / \mathrm{HOBr}$ is the stronger acidbyproviding your reasons" in the $1^{\text {st }}$ and $8^{\text {th }}$ semesters 
are provided in Graph 5. Examples of the answers provided by the science teacher candidate $\mathrm{E}$ in both semesters are shown in Figure 9 and Figure 10.

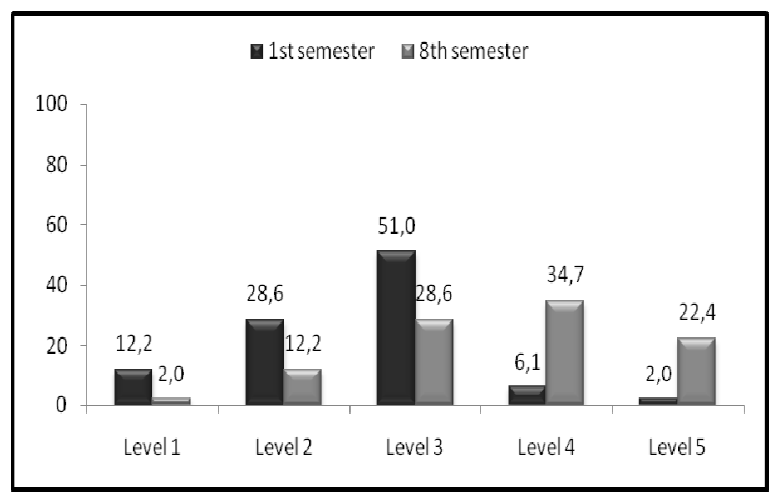

Graph 5. The percentage distributions of the answers to question 5

In the $1^{\text {st }}$ semester, $51.0 \%$ of the teacher candidates provided partially correct explanations (level 3) regarding which one of the $\mathrm{HOCl} / \mathrm{HOBr}$ oxy acids is stronger and why, while $34.7 \%$ provided correct but incomplete explanations (level 4 ) in the $8^{\text {th }}$ semester.It was determined that $22.4 \%$ of the teacher candidates provided entirely correct explanations (level 5).

Acidity decreases when moving downwards on the periodic table. As $\mathrm{Cl}$ is above $\mathrm{Br}, \mathrm{HOCl}$ is the stronger acid.

Figure 9. Science teacher candidate E's answer to question 5 in the $1^{\text {st }}$ semester

When Figure 9 is evaluated, it can be seen that teacher candidate $\mathrm{E}$ described the compound $\mathrm{HOCl}$ as more acidic without correctly explaining electronegativity, which actually affects the strength of oxy acids. The teacher candidate's explanation includes only partially correct information.

HOCl is a stronger acid than the $\mathrm{HOBr}$ compound.
Because, if we consider themfrom the standpoint of
electronegativity, Cl is more electronegative than Br,
and the Cl atom will draw the electrons closer to itself,
making it easier remove a proton from the Cl compound.

Figure 10. Science teacher candidate E's answer to question 5 in the $8^{\text {th }}$ semester

As it can be seen in Figure 10, the science teacher candidate E explained the underlying cause for the strength of binary oxy acids in the $8^{\text {th }}$ semester by drawing Lewis structures. In this example, the teacher candidate provided an entirely correct and complete answer by explaining acid strength based on $\mathrm{Cl}$ and Br's electronegativity.

The percentage distribution of answers to given by the science teacher candidates to the question "Explain which one of the acids $\mathrm{H}_{2} \mathrm{SO}_{4} / \mathrm{H}_{2} \mathrm{SO}_{3}$ is the stronger acid, by providing your reasons" in the $1^{\text {st }}$ and $8^{\text {th }}$ semesters are provided with respect to the level groups in Graph 6 . Examples of the answers provided by the science teacher candidate $\mathrm{F}$ in both semesters are shown in Figure 11 and Figure 12.

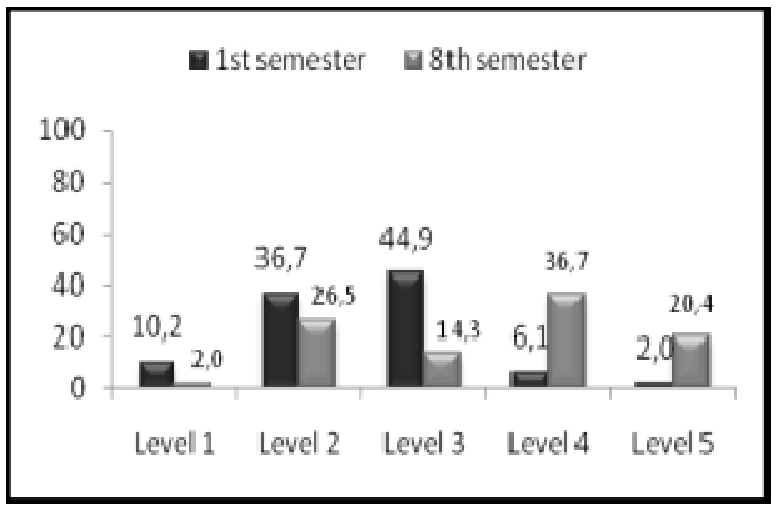

Graph 6. The percentage distributions of the answers to question 6

In the $1^{\text {st }}$ semester, $44.9 \%$ of the teacher candidates provided partially correct explanations (level 3) regarding which one of the $\mathrm{H}_{2} \mathrm{SO} 4 / \mathrm{H}_{2} \mathrm{SO}_{3}$ oxy acids is stronger and why, while a large percentage of $36.7 \%$ provided incorrect answers (level 2) to the question. In the $8^{\text {th }}$ semester, on the other hand, $36.7 \%$ provided correct but incomplete explanations (level 4), while $20.4 \%$ had increased their level of knowledge such that they were able to provide entirely correct explanations (level 5).

"Between $\mathrm{H}_{2} \mathrm{SO}_{4}$ and $\mathrm{H}_{2} \mathrm{SO}_{3}, \mathrm{H}_{2} \mathrm{SO}_{4}<\mathrm{H}_{2} \mathrm{SO}_{3}$ in terms of acid strength. This is because of the decreasing number of $O$."

Figure 11. Science teacher candidate $F^{\prime}$ s answer to question 6 in the $1^{\text {st }}$ semester

When Figure 11 is evaluated, it can be seen that the science teacher candidate $\mathrm{F}$ answered the question on the strength of oxyacids by describing $\mathrm{H}_{2} \mathrm{SO}_{4}$ as the weaker acid due to a higher number of $\mathrm{O}$ atoms. This demonstrates that the teacher candidate had incorrect knowledge on the subject.

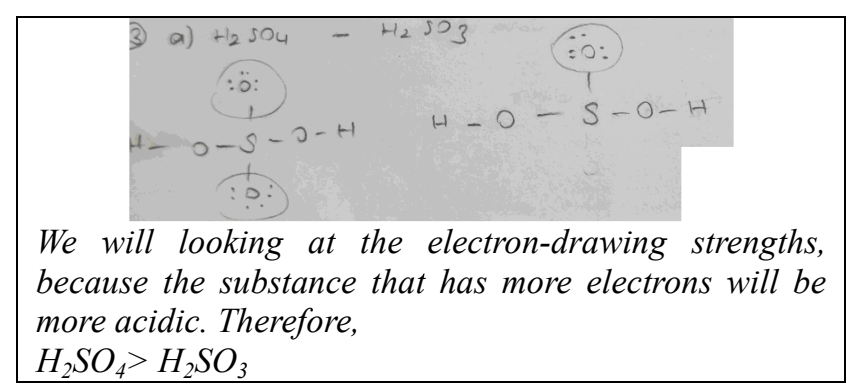

Figure 12. Science teacher candidate $F^{\prime}$ s answer to question 6 in the $8^{\text {th }}$ semester

As it can be seen in Figure 12, the science teacher candidate $\mathrm{F}$ explained the underlying cause for the strength of the given binary oxy acids in the $8^{\text {th }}$ semester by drawing 
Lewis structures.In this example, it can be seen that the teacher candidate provided an entirely correct and complete explanation by looking at the number of terminal oxygen atoms.

The percentage distribution of the answers given by the science teacher candidates to the question "Explain which one of the compounds $\mathrm{CH}_{3} \mathrm{COOH} / \mathrm{CH}_{3} \mathrm{CH}_{2} \mathrm{OH}$ is the stronger acidbyproviding your reasons" in the $1^{\text {st }}$ and $8^{\text {th }}$ semesters are provided with respect to the level groups in Graph 7. Examples of the answers provided by the science teacher candidate $G$ in both semesters are shown in Figure 13 and Figure 14.

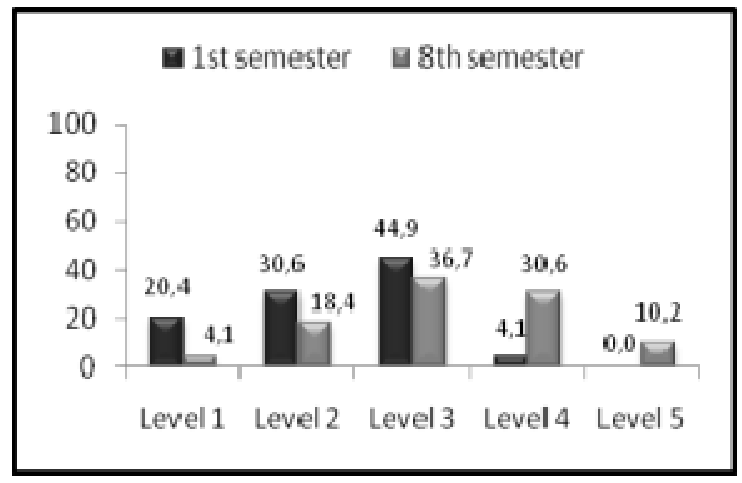

Graph 7. The percentage distributions of the answers to question 7

In the $1^{\text {st }}$ semester, $44.9 \%$ of the teacher candidates provided partially correct explanations (level 3) regarding which one of the $\mathrm{CH}_{3} \mathrm{COOH} / \mathrm{CH}_{3} \mathrm{CH}_{2} \mathrm{OH}$ acids is stronger and why, while a large percentage of $30.6 \%$ provided incorrect answers (level 2) to the question. In the $8^{\text {th }}$ semester, on the other hand, $36.7 \%$ provided partially correct explanations (level 4), while $30.6 \%$ provided correct but incomplete explanations (level 4). It was also noted that the percentage of entirely correct answers (level 5 ) increased from $0.0 \%$ in the $1^{\text {st }}$ semester to $10.2 \%$ in the $8^{\text {th }}$ semester.

" $\mathrm{CH}_{3} \mathrm{COO}$ His the stronger, because it has more oxygen atoms than ethyl alcohol."

Figure 13. Science teacher candidate $G^{\prime}$ s answer to question 7 in the $1^{\text {st }}$ semester

When Figure 13 is evaluated, the science teacher candidate G's explanation that the organic acid with more $\mathrm{O}$ atoms is the stronger acid demonstrates incorrect knowledge on the teacher candidate's part.

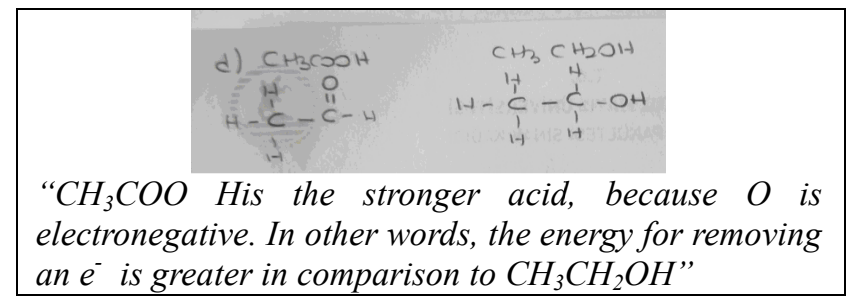

Figure 14. Science teacher candidate $G^{\prime}$ s answer to question 7 in the $8^{\text {th }}$ semester
As it can be seen in Figure 14, the science teacher candidate $G$ explained the strength of organic acids in the $8^{\text {th }}$ semester by drawing Lewis structures. However, in this example, the teacher candidate has made an error when drawing the Lewis structure by writing omitting an oxygen atom within the $-\mathrm{COOH}$ group.However, the teacher candidate demonstrated partially correct knowledge by emphasizing the importance of electronegativity.

The percentage distribution of the answers given by the science teacher candidates to the question "Explain which one of the compounds $\mathrm{CH}_{3} \mathrm{COOH} / \mathrm{CH}_{3}\left(\mathrm{CH}_{2}\right)_{6} \mathrm{COOH}$ is the stronger acid byproviding your reasons" in the $1^{\text {st }}$ and $8^{\text {th }}$ semesters are provided with respect to the level groups in Graph 8. Examples of the answers provided by the science teachercandidateH in both semesters are shown in Figure 15 and Figure 16.

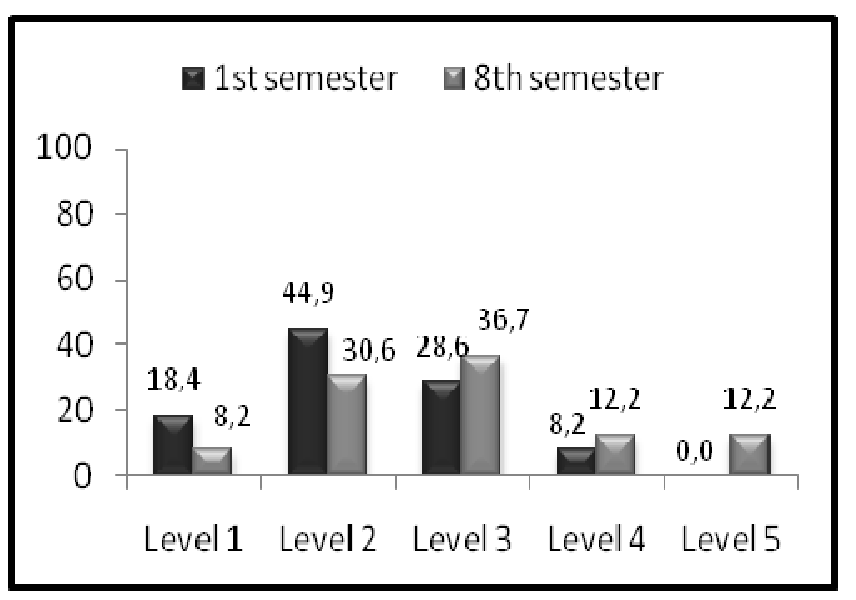

Graph 8. The percentage distributions of the answers to question 8

In the $1^{\text {st }}$ semester, it was noted that a large percentage of $44.9 \%$ of the teacher candidates provided incorrect explanations (level 2) regarding which one of the $\mathrm{CH}_{3} \mathrm{COOH} / \mathrm{CH}_{3}\left(\mathrm{CH}_{2}\right)_{6} \mathrm{COOH}$ acids is stronger and why, while none of the teacher candidates provided an entirely correct answer (level 5) to the question. In the $8^{\text {th }}$ semester, on the other hand, $36.7 \%$ provided partially correct explanations (level 5), while $12.2 \%$ provided entirely correct explanations (level 5).

$\mathrm{CH}_{3}\left(\mathrm{CH}_{2}\right)_{6} \mathrm{COOH}$ is the stronger acid, because its number of carbon atoms, and the number of hydrogen atoms attached to them, is higher.

Figure 15. Science teacher candidate $H^{\prime}$ s answer to question 8 in the $1^{\text {st }}$ semester

When Figure 15 is evaluated, it can be seen that the science teacher candidate $\mathrm{H}$ described $\mathrm{CH}_{3}\left(\mathrm{CH}_{2}\right)_{6} \mathrm{COOH}$ as the stronger acid due to its higher number of carbon and hydrogen atoms.It was hence determined that the teacher candidate had incorrect knowledge regarding the strength of organic acids. 


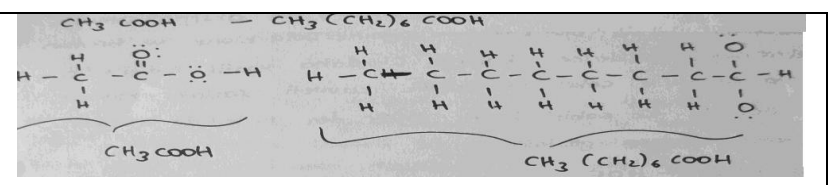

$\mathrm{CH}_{3}\left(\mathrm{CH}_{2}\right)_{6} \mathrm{COOH}$ is a stronger acid than $\mathrm{CH}_{3} \mathrm{COOH}$. As the number of carbon atoms increase, so does the ability to drawelectrons. The second structure above is more distributed and branched. Since each carbon will draw an e-, and since they will draw more on the $\mathrm{O}-\mathrm{H}$ bond, it is the stronger acid.

Figure 16. Science teacher candidate H's answer to question 8 in the $8^{\text {th }}$ semester

As it can be seen in Figure 16, the science teacher candidate $\mathrm{H}$ explained the strength of organic acids in the $8^{\text {th }}$ semester as being related to the length of the carbon chain by drawing Lewis structures.However, when describing that acidity will increase due to the $\mathrm{C}$ atoms ability to draw electrons, the teacher candidate failed to take into account the fact that the carbon chain length has a very limited effect on acid strength.

The percentage distribution of the answers given by the science teacher candidates to the question "Explain which one of the acids $\mathrm{CH}_{3} \mathrm{COOH} / \mathrm{CH}_{3} \mathrm{CH}_{2} \mathrm{ClCOOH}$ is the stronger acid by providing your reasons" in the $1^{\text {st }}$ and $8^{\text {th }}$ semesters are provided with respect to the level groups in Graph 9. Examples of the answers provided by the science teacher candidate $\mathrm{K}$ in both semesters are shown in Figure 17 and Figure 18.

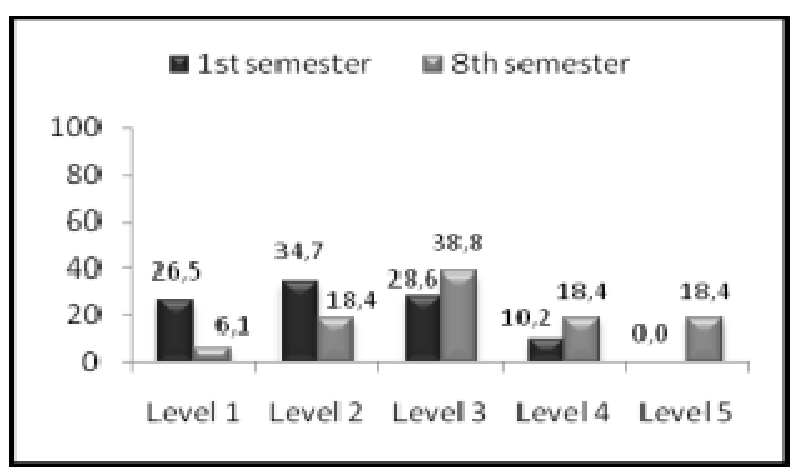

Graph 9. The percentage distributions of the answers to question 9

In the $1^{\text {st }}$ semester, $34.7 \%$ of the teacher candidates provided incorrect explanations (level 2) regarding which one of the $\mathrm{CH}_{3} \mathrm{COO} / \mathrm{CH}_{3} \mathrm{CH}_{2} \mathrm{ClCOOH}$ oxy acids is stronger and why, while $38.8 \%$ provided partially correct explanations (level 3 ) in the $8^{\text {th }}$ semester. It was also noted that the percentage of entirely correct answers (level 5) increased from $0.0 \%$ in the $1^{\text {st }}$ semester to $18.4 \%$ in the $8^{\text {th }}$ semester.

$\mathrm{CH}_{2} \mathrm{ClCOOH}$ is the stronger acid, because it has a $\mathrm{Cl}$ atom, which can react with the ion of a stronger base.

Figure 17. Science teacher candidate $K^{\prime}$ s answer to question 9 in the $1^{\text {st }}$ semester
When Figure 17 is evaluated, it can be seen that the science teacher candidate $\mathrm{K}$ demonstrated partially correct information by accurately describing the stronger acid $\left(\mathrm{CH}_{2} \mathrm{ClCOOH}\right)$, yet providing a wrong explanation for the actual effect of the $\mathrm{Cl}$ atom in the strength ranking of the organic acids in question.

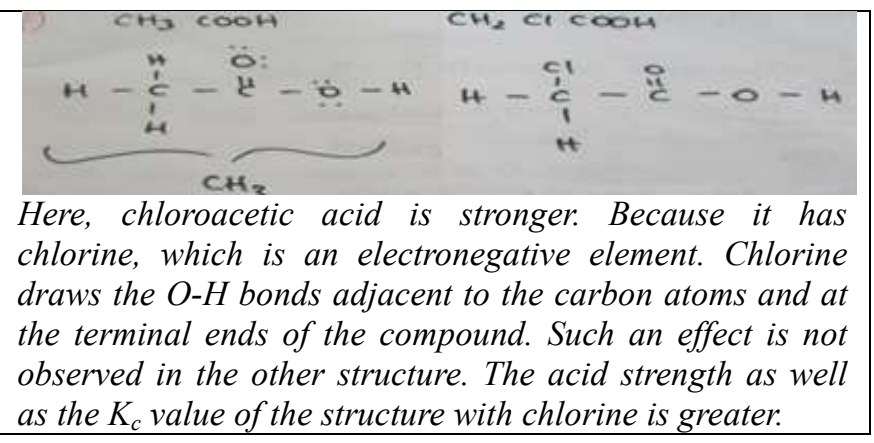

Figure 18. Science teacher candidate $F^{\prime}$ s answer to question 9 in the $8^{\text {th }}$ semester

As it can be seen in Figure 18, the science teacher candidate $\mathrm{K}$ demonstrated entirely correct and complete knowledge when listing the strength of the organic acids by drawing the Lewis structure of the compounds, and explaining that the $\mathrm{Cl}$ atom increased the acid strength due to its electronegativity.

\section{Conclusions and Discussion}

The most important factor that affects learning is the students' preliminary knowledge. Students structure new information in their minds by using preliminary knowledge. It is important to remedy students' misconceptions and lack of knowledge on a given subject by first identifying their preliminary knowledge. When the learningofscience teacher candidates pertaining to the concept of acids(as one of the fundamental subjects of chemistry) from chemistry courses in previous stages of their education is considered, it can be seen that there are continuing misconceptions and a general lack of knowledge regarding acids. This shows the necessity to place greater emphasis on this subject in university chemistry courses.

It was observed that, as preliminary knowledge, some of the teacher candidates considered acid strength to be related to ionization. It was also observed that they had insufficient knowledge on the effects of electronegativity, bond dissociation energy, bond structure and bond length. The importance of bond polarity, which affects the strength of binary acids formed by elements within the same period, was not mentioned and neither was the importance of differences in the electronegativity of atoms forming a bond.When describing the acid strength of oxy acids, the provided explanations did not take into account the effect of electronegativity.In addition, the effect of terminal oxygen atoms on the strength of oxy acids was not mentioned. The teacher candidates were unable to describe that the carbon chain length of organic acids had minimal 
effect on their acid strength. Similarly to our study, Köseoğlu, Budak and Kavak (2002) determined that students harbored the misconception that acid strength depended not on the type or nature of the substance, but rather on an increasing number of $\mathrm{H}$ atoms.

In the $8^{\text {th }}$ semester, it was observed that the science teacher candidates attempted to provide explanations by drawing Lewis structures for questions asking them to compare oxy and organic acids. With the Lewis structure that were drawn, the teacher candidates endeavored to generally describe the effects of bond structure, terminal oxygen atoms and central atoms on acidity, as well as the importance of bond length.However, it was observed that providing the correct explanations also required that they draw the Lewis structures accurately.

When the study results are evaluated, it can be seen that drawings and written answers can contribute to determining the scope of knowledge of science teacher candidates, and that these drawing can be used to reveal the teacher candidates' level of learning in various subjects, as well as the means they use to express what they have learned. In the studies conducted by Yörek (2007), Bartoszeck, Machado and Amann-Gainotti (2008), Kara, Avc1 and Çekbaş (2008), Uzunkavak (2009a, 2009b), and Çelikler and Topal (2011), the knowledge of students were assessed with the aid of drawings, and it was concluded that drawings provided a more meaningful mean for determining the students' knowledge.

In conclusion, it was determined that the levels of readiness of the science teacher candidates were insufficient, despite of the fact that the subjects covered within the scope of the study were explained and taught as a part of their high school curriculum. By the time of graduation, it was observed that the large majority of the science teacher candidates' incorrect or partially correct knowledge regarding binary, organic and oxy acid strengths had improved and changed into correct knowledge. However, it was noted that the science teacher candidates still continued to harbor incorrect knowledge on certain subjects. Acids are one of the fundamental subjects of chemistry, and it is believed that education on acids can be rendered more interesting from the students' standpoint if the subject were to be conveyed in a more concrete fashion by actively involving the students in the learning processes, making associations with daily life, and designing experiments. Under these circumstances, meaningful and lasting learning would be achieved at high school, improving the levels of readiness of science teacher candidates, and ensuring that a subject of this level of importance is learned in a full and complete manner. In addition, by reflecting in detail the level of knowledge of science teacher candidates on binary, organic and oxy acids, we believe that this study will fill a gap in literature on this subject, providing depth as well as contributing to the literature in this respect.

\section{References}

[1] Ayas, A. (2006). Kavram Öğrenimi. "Fen ve teknoloji öğretimi” (Ed. S. Çepni). Ankara: Pegema Yayıncılık.

[2] Bartoszeck, A.B. , Machado, D.Z. \& Amann-Gainotti, M. (2008). Representations of internal body image: a study of preadolescents and adolescent students in Araucaria, Paraná, Brazil. Ciências \& Cognição, 13 (2), s. 139-159.

[3] Başaran, İ. E. (1998). Eğitim psikolojisi (5. Baskı). Ankara: Aydan Web Tesisleri.

[4] Binbaşığlu, C. (1995). Eğitim psikolojisi (9. Baskı). Ankara: Yargic1 Matbaa.

[5] Bloom, B. (1995). İnsan nitelikleri ve okulda öğrenme (2. Bask1). (Çeviren: D. A. Özçelik). Ankara: Milli Eğitim Basımevi.

[6] Çelikler, D. \& Topal, N. (2011). İlköğretim Fen Bilgisi Ögretmen Adaylarının Karbondioksit ve $\mathrm{Su}$ Döngüsü Konusundaki Bilgilerinin Çizim İle Saptanması. Journal of Educational and Instructional Studies in the World, 1(1), 72-79.

[7] Ersanl1, K. \& Uzman, E. (Ed). (2007). Eğitim psikolojisi. İstanbul: Lisans Yayıncılı.

[8] Kara,İ., Avc1, E. D. \& Çekbaş, Y. (2008). Fen bilgisi öğretmen adaylarının 1şık kavramı ile ilgili bilgi düzeylerinin araştırılması. Mehmet Akif Ersoy Üniversitesi Eğitim Fakültesi Dergisi, Aralık 2008. (10.11.2010) http://efd.mehmetakif.edu.tr/arsiv/aralik2008/46-57.html

[9] Köseoğlu, F., Budak, B. \& Kavak, N. (2002). Yapılandırıcı öğrenme teorisine dayanan ders materyali - öğretmen adaylarına asit-baz konusu ile ilgili kavramların öğretilmesi. ODTU Eğitim Fakültesi VI. Fen Bilimleri Sempozyumu. Ankara.

[10] Uzunkavak, M. (2009a). Öğrencilerin Newton Kanunları bilgilerinin yazı ve çizim metoduyla karşılaştırılması. SDU International Journal of Technologic Sciences, 1(1), s. 2940.

[11] Uzunkavak, M. (2009b). Öğrencilerin iş kavramında pozitiflik-negatiflik ayrımı becerilerinin yazı ve çizim metoduyla ortaya çıkarılması. SDU International Journal of Technologic Sciences 1(2), s. 10-20.

[12] Ülgen, G. (1997). Eğitim psikolojisi. İstanbul: Alkım Yayınevi.

[13] White, R.T. \& Gunstone, R. F. (1992). Probing understanding. London: The Falmer Pres.

[14] Yenilmez, K. \& Kakmac1, Ö. (2008). İlköğretim yedinci sınıf öğrencilerinin matematikteki hazır bulunuşluk düzeyi. Kastamonu Eğitim Dergisi, 16(2), 529-542.

[15] Yılmaz, H. \& Sünbül, A. M. (2003). Öğretimde planlama ve değerlendirme. Ankara: Mikro Yayınları.

[16] Yörek, N. (2007). Öğrenci çizim yoluyla 9 ve 11. sınıf öğrencilerinin hücre konusunda kavramsal anlama düzeylerinin belirlenmesi. Dokuz Eylül Üniversitesi Buca Eğitim Fakültesi Dergisi, 22. s. 107-114.

[17] Yüksel, A., Marangoz, D.Ç. ve Canaran, N.T. (2004). Farklılaştırılmış öğretim stratejileri. (09.04.2011) http://www.erg.sabanciuniv.edu/iok2004/bildiriler/Arzu\%20 Yuksel.doc 